\title{
Additional Lake Bob Sandlin Sites with Documented Collections of Prehistoric Lithic and Ceramic Artifacts
}

Timothy K. Perttula

Heritage Research Center, Stephen F. Austin State University

Bo Nelson

Heritage Research Center, Stephen F. Austin State University

Patti Haskins

Follow this and additional works at: https://scholarworks.sfasu.edu/ita

Part of the American Material Culture Commons, Archaeological Anthropology Commons, Environmental Studies Commons, Other American Studies Commons, Other Arts and Humanities Commons, Other History of Art, Architecture, and Archaeology Commons, and the United States History Commons

Tell us how this article helped you.

This Article is brought to you for free and open access by the Center for Regional Heritage Research at SFA ScholarWorks. It has been accepted for inclusion in Index of Texas Archaeology: Open Access Gray Literature from the Lone Star State by an authorized editor of SFA ScholarWorks. For more information, please contact cdsscholarworks@sfasu.edu. 
Additional Lake Bob Sandlin Sites with Documented Collections of Prehistoric Lithic and Ceramic Artifacts

\section{Creative Commons License}

\section{(c) (1) (8)}

This work is licensed under a Creative Commons Attribution-NonCommercial 4.0 International License 


\title{
Additional Lake Bob Sandlin Sites with Documented Collections of Prehistoric Lithic and Ceramic Artifacts
}

\author{
Timothy K. Perttula, Bo Nelson, and Patti Haskins
}

\section{INTRODUCTION}

This is the third in a series of publications that concern the documentation of prehistoric artifact collections from sites found along the shoreline of Lake Bob Sandlin in the Big Cypress Creek basin of East Texas (Nelson and Perttula 2003; Perttula et al. 2010). These documentation efforts have demonstrated that sites at the lake have diverse temporal and spatial patterns, with an intensive Caddo occupation from the Middle (ca. A.D. 1200-1425) to Latc Caddo (ca. A.D. 1430-1680) periods (Perttula and Nelson 2003).

\section{The Sites}

Our recent documentation efforts include moderate collections of prehistoric ceramic ( $\mathrm{n}=974$ sherds, including 711 plain rim, body, and base shcrds and 263 decorated rim and body sherds) and lithic artifacts ( $\mathrm{n}=324$, primarily consisting of 276 pieces of lithic debris, 21 dart points, and 12 bifaces), as well as a few pieccs of burned clay and daub; there are very small amounts of late $19^{\text {th }}$-early $20^{\text {th }}$ century artifacts from three of the sites. These are from five sites along the now-inundated Big Cypress Creek valley.

\section{Dead Oak or Trailer House Cove (41CP288)}

Nelson and Perttula (2003:37) described the Dead Oak or Trailer House Cove site as covcring about 2 acres of an upper ridge slope (330-350 ft. amsl) ca. $400 \mathrm{~m}$ south of an old channel of Big Cypress Creek. Archaeological materials documented by Nelson and Pcrttula (2003) suggest that the principal component at the site was a pre-A.D. 1200/1300 Early Caddo occupation, although Woodland and Late Archaic dart points have also been reported from the site.

The recently documented collection from the Dead Oak site has 340 sherds. This includes 241 plain shcrds (five rim, 12 base, and 224 body sherds) and 99 rim and body sherds (Table 1). The plain to decorated sherd ratio (P/DR) is 2.43. Most of the sherds are from vessels tempered with grog (71\%), but $28 \%$ are from bone-tempered vessels, and $0.3 \%$ are from hematite-tempered vessels. Of the decorated sherds, $86 \%$ are from utility wares, and the remaining $14 \%$ are from engraved fine wares.

The most common utility wares have fingernail punctated (35\% of the decorated sherds) and tool punctated (20\%) decorativc clements (see Table 1), either in rows or frecly placed on the rim and vessel body. Approximately $18 \%$ of the decorated sherds (and $73 \%$ of the rims in the collection) have incised designs, primarily horizontal, diagonal, and cross-hatched elements from Canton Incised, Dunkin Incised, and Davis Incised vessels. Approximately $6 \%$ of the sherds have incised-punctated elements. These include straight and rectangular incised zones filled with tool and fingernail punctations; these may be from Pennington Punctated-Incised vessels. This combination of decorative elements and sherds from identified types, along with the P/DR value of 2.43 , and the fact that $6 \%$ of the decorated sherds are brushed, suggests that the principal Caddo use of the site took at ca. A.D. 1200-1300, in the first part of the Middle Caddo period. 
Table 1. Decorated sherds from the Dead Oak site.

\begin{tabular}{|c|c|c|c|}
\hline Decorative element & Rim & Body & $\mathrm{N}$ \\
\hline \multicolumn{4}{|l|}{ Utility Ware } \\
\hline cross-hatched incised lines & - & 1 & 1 \\
\hline diagonal incised lines & 4 & - & 4 \\
\hline diagonal and opposed incised lines & 1 & 1 & 2 \\
\hline horizontal incised lines & 3 & - & 3 \\
\hline parallel incised lines & - & 8 & 8 \\
\hline zoned incised-punctated, rectangular & 1 & 1 & 2 \\
\hline $\begin{array}{l}\text { straight incised line adjacent to tool } \\
\text { punctated zone }\end{array}$ & - & 2 & 2 \\
\hline $\begin{array}{l}\text { parallel incised lines adjacent to } \\
\text { fingernail punctates }\end{array}$ & - & 1 & 1 \\
\hline $\begin{array}{l}\text { straight and opposed incised lines } \\
\text { and tool punctated zone }\end{array}$ & - & 1 & 1 \\
\hline tool punctated rows & - & 16 & 16 \\
\hline tool punctated, free & - & 2 & 2 \\
\hline single tool punctate & - & 2 & 2 \\
\hline single fingernail punctate & - & 4 & 4 \\
\hline fingernail punctated, free & - & 11 & 11 \\
\hline fingernail punctated rows & - & 20 & 20 \\
\hline Subtotal, utility wares & 9 & 76 & 85 \\
\hline \multicolumn{4}{|l|}{ Fine Ware } \\
\hline diagonal engraved lines & 2 & - & 2 \\
\hline diagonal and opposed engraved lines & - & 1 & 1 \\
\hline parallel lines and excised zone & - & 1 & 1 \\
\hline parallel engraved lines & - & $4^{*}$ & 4 \\
\hline straight engraved line & - & 1 & 1 \\
\hline concentric engraved lines & - & 1 & 1 \\
\hline $\begin{array}{l}\text { circular engraved lines with hatched } \\
\text { pendant triangles }\end{array}$ & - & 2 & 2 \\
\hline curvilinear engraved lines & - & 2 & 2 \\
\hline Subtotal, fine wares & 2 & 12 & 14 \\
\hline Totals & 11 & 88 & 99 \\
\hline
\end{tabular}

*includes one bottle sherd

It was noted during the documcntation process that thin Caddo sherds were primarily from the southeastern portion of the site, while thicker sherds, many of them plain (possibly from an earlier Caddo occupation or even a Woodland occupation), were from the northern portion of the landform. These latter sherds were in an area where various dart points had also been recovered. 
The lithic artifact assemblage in the most recently documented collection from the Dead Oak site appears to be almost exclusively the product of pre-A.D. 800 Woodland, Late Archaic, and possible Middle Archaic occupations. The one Caddo associated lithic artifact is a partially pecked and polished celt preform of siliceous shale (with a source area in the Onachita Mountains of southeastern Oklahoma and Red River gravels) (see Turner et al. 2011:260). The remainder of the assemblage includes 11 dart points, three biface fragments, a chipped stone flake tool, three ground stone tools, and 159 pieces of lithic debris.

The dart points from the site include a dart point tip made from a non-local orange novaculite as well as others that can bc identified by type and probable temporal period of use and manufacture (cf. Turner et al. 2011). The earliest point in the collection is a probable Middle Archaic form with side notches and a flat base; it is madc from a heat-treated novaculite. The five Late Archaic points are represented by three quartzite Yarbrough points, a quartzite Wells point, and a quartzite Williams dart point. The Woodland dart points at the Dead Oak site include Gary $(n=2)$ and Godley $(n=1)$ specimens made from a local quartzite, as well as a narrow parallel-stemmed dart point (cf. Darl) made from a grayish-black novaculite.

The biface fragments are made from local quartzite $(n=2)$ and a non-local white novaculite $(n=1)$. The last chipped stone tool is a side scraper made from a non-local white chert. Approximately $33 \%$ of the chipped stones in this collection are inade from non-local lithic raw materials that appear to have originated from Ouachita Mountains source areas and/or the Red River gravels. Other than the aforementioned celt, the other ground stone tools include a ferruginous sandstone bi-pitted stone and a quartzite hammerstone fragment.

The lithic debris from the site in the documented collection is dominated by local raw materials, namcly petrified wood $(n=95)$ and quartzite $(n=63)$. The one remaining piece of lithic debris is of quartz, a hard to knap non-local raw material whose source areas lie in bedrock formations in the Ouachita Mountains and in Red River gravels well to the north of the Dead Oak site.

\section{West Island (41TT208)}

The West Island site was first recorded by Southern Methodist University during the archaeological survey at Lake Bob Sandlin done in the early 1970s. The site form states that there was a "low density or amounts of lithic and ceramics," and that the site "must be seasonal camp." It was located on an elevated landform ( $335 \mathrm{ft}$. amsl) in the Big Cypress Creek floodplain. It is now a small island in the lake during normal pool elevations.

The ceramic assemblage from the West Island documented collection includes 34 decorated rim and body sherds (Table 2), 79 plain body sherds, and 11 plain base sherds. Most of the plain body and base sherds are from two vessel sections, one tempered with bone ( $n=20$ sherds) and the other with bone and grog ( $n=39$ sherds).

The decorated sherds from this site are dominated by utility wares ( $88 \%)$, particularly sherds from vessels with incised (50\% of the decorated sherds), punctated (26\%), incised-punctated $(6 \%)$, and brushed $(6 \%)$ decorative elements. The incised sherds are from Canton Incised (cross-hatched decoralive element) and Dunkin Incised (diagonal and diagonal-opposed incised elements). Among the fine wares, which account for only $12 \%$ of the decorated sherds from the West Island site, the grog-tempered red-slipped sherds may be from Sanders Plain vessels (cf. Brown 1996). Given the predominance of incised and punctated sherds in the documented collection, the relatively low frequency of sherds with brushing, and the red-slipped sherds, the West Island Caddo occupation likely took place in the early part of the Middle Caddo period.

Discounting the sherds from the two previously mentioned vessel sections, the majority of the sherds from the West Island collection are from vessels tempered with grog (79\%). Approximately $5.9 \%$ of the sherds are bone tempered, and $15.4 \%$ are from grog-bone-tempered vessels. 
Table 2. Decorated sherds from the West Island site.

\begin{tabular}{|c|c|c|c|}
\hline Decorative element & Rim & Body & $\mathrm{N}$ \\
\hline \multicolumn{4}{|l|}{ Utility Ware } \\
\hline parallel appliqued ridges & - & 1 & 1 \\
\hline parallel brushed & - & 2 & 2 \\
\hline cross hatched incised lines & - & 1 & 1 \\
\hline diagonal incised lines & 1 & - & 1 \\
\hline diagonal-opposed incised lines & - & 1 & 1 \\
\hline parallel incised lines & - & 7 & 7 \\
\hline parallel and opposed incised lines & - & 2 & 2 \\
\hline straight incised line & - & 4 & 4 \\
\hline straight and opposed incised lines & - & 1 & 1 \\
\hline $\begin{array}{l}\text { diagonal incised line and tool } \\
\text { punctated-filled triangle }\end{array}$ & 1 & - & 1 \\
\hline $\begin{array}{l}\text { diagonal and vertical incised lines } \\
\text { and tool punctated-filled triangle }\end{array}$ & 1 & - & 1 \\
\hline fingernail punctated rows & - & 3 & 3 \\
\hline fingernail punctated, free & - & 1 & 1 \\
\hline linear tool punctated & - & 1 & 1 \\
\hline tool punctated rows & - & 3 & 3 \\
\hline tool punctated, free & 1 & - & 1 \\
\hline Subtotal, utility wares & 4 & 26 & 30 \\
\hline \multicolumn{4}{|l|}{ Fine Ware } \\
\hline int/ext. red-slipped & - & 2 & 2 \\
\hline horizontal and diagonal engraved lines & - & 1 & 1 \\
\hline straight engraved line* & - & 1 & 1 \\
\hline Subtotal, fine wares & 0 & 4 & 4 \\
\hline Totals & 4 & 30 & 34 \\
\hline
\end{tabular}

*bottle sherd

In addition to the ceramic vessel sherds, there is a single piece of burned clay in the recently documented collections from the West Island site as well as two pieces of daub. The former may be the remnants of at clay lined hearth or earth oven, while the daub is an indication that there may be remnants of burned clay and thatch-covered Caddo structures at the site.

The prehistoric lithic artifacts are sparse in this collection from the West Island. They include two heattreated picces of local quartzite lithic debris and a quartzite fire-cracked rock.

\section{East Island (41TT209)}

Nelson and Perttula (2003:58) noted that this site is on a small island (the top of an alluvial terrace landform or alluvial knoll in the Big Cypress Creek floodplain) just to the north of the Road Islands or Titus Islands site (41TT804), and a short distance east of the West Island site. Archaeological materials known to come from East Island suggest that it was occupied in Late Caddo Titus phase times (ca. A.D. 1430-1680). When the site was recorded by Southern Methodist University in the 1970s. only a low density of prehistoric ceramic sherds and lithic debris were reporled to have corne from it. 
The ceramic assemblage from recently documented collections comprises 50 sherds, 23 plain body and base sherds and 27 decorated rim and body sherds (Table 3). The P/DR is 0.85 , consistent with a Late Caddo ceramic component in the Big Cypress stream basin. The one fine ware engraved body sherd, however, has finely executed opposed diagonal engraved lines, and compares favorably to Holly Fine Engraved, a preA.D. 1300 ceramic type in this part of East Texas (see Story 2000).

Table 3. Decorated sherds from the East Island site.

\begin{tabular}{|c|c|c|c|}
\hline Decorative element & $\operatorname{Rim}$ & Body & $\mathrm{N}$ \\
\hline \multicolumn{4}{|l|}{ Utility Ware } \\
\hline parallel brushed & - & 5 & 5 \\
\hline opposed curvilinear incised lines & - & 1 & 1 \\
\hline diagonal incised lines & 2 & - & 2 \\
\hline horizontal incised lines & 1 & - & 1 \\
\hline parallel incised lines & - & 5 & 5 \\
\hline parallel incised lines and tool punctated zone & - & 1 & 1 \\
\hline horizontal neck banding & 1 & - & 1 \\
\hline parallel pinched-ridged & - & 1 & 1 \\
\hline fingernail punctated, free & - & 1 & 1 \\
\hline fingernail punctated rows & - & 6 & 6 \\
\hline tool punctated rows & - & 2 & 2 \\
\hline Subtotal, utility ware & 4 & 22 & 26 \\
\hline \multicolumn{4}{|l|}{ Fine Ware } \\
\hline opposed diagonal engraved lines & - & 1 & 1 \\
\hline Subtotal, fine ware & 0 & 1 & 1 \\
\hline Totals & 4 & 23 & 27 \\
\hline
\end{tabular}

The other decorated sherds from the East Island site are from utility ware vessels, including all four rims. The sherds have punctated (33\% of all the decorated sherds), incised (33\%), brushed (19\%), incisedpunctated (4\%), neck banded (4\%), and pinched (4\%) decorative clements (see Table 3). The brushed sherds are likely from Bullard Brushed vessels, the one neck banded sherd is from a LaRue Neck Banded jar, and the pinched-ridged body sherd is likely from a Killough Pinched vessel; the appearance of these utility types is consistent with a Late Caddo occupation at the site. The incised, incised-punctated, and punctated sherds may be from a variety of different Late Caddo utility wares, although none can be identified to a currently defined type.

The sherds are from vessels primarily tempered with grog (84\%). Others are tempered with grog and bone $(n=3,6 \%)$ or bone $(n=6,12 \%)$

The only lithic artifacts from the East Island site are 14 pieces of lithic debris from on-site chipped tool manufacture and maintenance activities. They include $93 \%$ that are on local raw materials (10 quartzite and three petrified wood) and $7 \%$ on non-local cherts (dark brown chert). About $57 \%$ of the lithic debris have cortical remnants, suggesting that pebbles and small cobbles were brought to the site for reduction, probably to produce suitable flakes for tools.

A possible mid- to late $19^{\text {th }}$ century use of the East Island site is noted by the one yellow ware body sherd and a patinated hand-made bottle glass lip. The peak period for yellow ware production in the United States was in the 1860s and 1870s (Leibowitz 1985). 


\section{TXU Park and Boat Ramp (41TT758)}

The TXU Park and Boat Ramp site, estimated to cover about 0.6 acres, is on a southward sloping ridge slope (330-340 ft. amsl) about $600 \mathrm{~m}$ north of an old and now inundated old channel ol Big Cypress Creek. In addition to evidence of Late Archaic use, the main prehistoric occupation appears to have taken place by Caddo peoples before A.D. 1200 (Nelson and Perttula 2003:51).

The ceramic assemblage from this site includes 221 plain sherds (seven rims, eight base, and 206 body) and 69 decorated sherds (Table 4). The P/DR is 3.20, consistent with a pre-A.D. 1200 Caddo ceramic component in the Big Cypress Creek valley. The majority of the sherds are from grog-tempered vessels (83\%), while $17 \%$ are bone-tempered.

Table 4. Decorated sherds from the TXU Park or Boat Ramp site.

\begin{tabular}{|c|c|c|c|}
\hline Decorative element & Rim & Body & $\mathrm{N}$ \\
\hline \multicolumn{4}{|l|}{ Utility Ware } \\
\hline diagonal incised lines & - & 1 & 1 \\
\hline diagonal opposed incised lines & 1 & 7 & 8 \\
\hline parallel incised lines & - & 5 & 5 \\
\hline straight incised lines & - & 3 & 3 \\
\hline $\begin{array}{l}\text { circular incised zone with small } \\
\text { circular punctates }\end{array}$ & - & 1 & 1 \\
\hline $\begin{array}{l}\text { parallel incised lines adjacent to a } \\
\text { tool punctated zone }\end{array}$ & - & 1 & 1 \\
\hline fingcrnail punctated, free & 1 & 10 & 11 \\
\hline fingernail punctated rows & - & 20 & 20 \\
\hline single fingernail punctate & - & 6 & 6 \\
\hline tool punctated rows & - & 3 & 3 \\
\hline Subtotal, utility wares & 2 & 57 & 59 \\
\hline \multicolumn{4}{|l|}{ Fine Ware } \\
\hline diagonal engraved lines & 1 & - & 1 \\
\hline horizontal engraved lines & $1^{*}$ & - & 1 \\
\hline horizontal and diagonal opposed engraved lines & - & $1 *$ & 1 \\
\hline parallel engraved lines & - & 1 & 1 \\
\hline parallel engraved lines and excised triangle & - & 1 & 1 \\
\hline parallel and opposed engraved lines & - & $1^{*}$ & 1 \\
\hline single curvilinear engraved line & - & 1 & 1 \\
\hline single straight engraved line & - & 2 & 2 \\
\hline vertical engraved lines & 1 & - & 1 \\
\hline Subtotal, fine wares & 3 & 7 & 10 \\
\hline Totals & 5 & 64 & 69 \\
\hline
\end{tabular}

*includes a bottle sherd

Almost $86 \%$ of the decorated sherds from the TXU 1ark and Boat Ramp site are from utility ware vessels (see Table 4); $14.5 \%$ of the decorated sherds are from engraved fine ware vessels. Most of these have fingernail and tool punctated decorative elements (58\% of all the decorated sherds) or geometric incised elements $(25 \%)$. Among the latter are Dunkin Incised vessel sherds. The remaining utility wares have incised-punctated elements, with triangular or circular incised zones filled with punctations. One of these 
shcrds may be from a Crockett Curvilinear Incised vessel because it has circular incised zoncs filled with small circular punctations (Suhm and Jelks 1962:Platc 17).

Among the engraved fine ware sherds are three body sherds from Holly Fine Engraved bottles and carinated bowls as well as one Hickory Engraved bottle sherd (see Table 4). The Holly Fine Engraved bottle sherds havc horizontal and opposed engraved lines on the vessel body, while the carinated bowl sherd has parallel engraved lines with a a large excised triangular arca (Suhm and Jelks 1962:Plate 39). Their occurrence among the TXU Park and Boat Ramp site decorated ceramics, along with the P/DR value of 3.20 , suggests that the main Caddo occupation here predates ca. A.D. 1200.

The lithic artifacts from the collections recently documented from the TXU Park and Boat Ramp site suggest the site was also occupied, probably episodically, during the Middle Archaic, Latc Archaic, and Woodland periods. The one possible Middle Archaic point is a sidc-notched specimen made from a non-local light grayishbrown chert. The Late Archaic points include three quartzite Yarbrough points and a quartzite parallel-stemmed form. Two contracting stem Gary dart points, made from quartzite and a brownish-red chert, are evidence of use of the site during the Woodland period. In addition to the dart points, there are two biface preforms made from local petrified wood and quartzite as well as a bifacially chipped knive made from a local brownish-red chert.

There is very slight evidence for the historic use of the site in the late $19^{\text {th }}$ century. There is a single ca. 1870-1890s lead-glazed stoneware sherd in the TXU Park and Boat Ramp site collection.

\section{Road Islands or Titus Islands (4ITT804)}

The Road Islands or Titus Islands site was described by Nelson and Perttula (2003:58) as situated on an alluvial terrace landform ( $335 \mathrm{ft}$. amsl) that is an island in the lake when lake levels arc below normal flood pool. It covers about 0.75 acres. Archaeological materials previously documented from the site indicate that it was occupied during Late Archaic, Woodland, and post-1890 times, but the principal occupation took place during the Middle Caddo period. There is evidence that the site has been disturbed by looting activities in the past.

The Caddo ceramic assemblage in the recently documented collections from the Road islands or Titus Islands site consists of 169 sherds. Approximately 80\% $(n=136)$ are plain rim $(n=5)$, base $(n=7)$, and body $(\mathrm{n}=124)$ sherds, and the remainder are decorated rim and body sherds (Table 5$)$. The P/DR is 4.12. As with the other Caddo ceramic assemblages at Lake Bob Sandlin, the majority of the sherds from the site are from grog-tempered vessels $(76.9 \%)$. The remaining $23.1 \%$ arc from bone-tempered vessels.

The diversity in the decorated sherds Irom the site suggests that there may have been two Caddo occupations, one that primarily dates before A.D. 1200 (with Holly Fine Engraved and Hickory Engraved, cane punctated sherds), and a second component that dates after ca. A.D. 1200 (perhaps dating even as late as ca. A.D. 1400) with brushed $(n=6)$ and appliqued $(n=1)$ utility warc sherds. There are no clear Late Caddo, Titus phase (i.e., Ripley Engraved) engraved fine ware sherds in the collection, which suggests this later component may have instead taken place during the Middle Caddo period.

The utility wares arc dominated by sherds from incised vessels (36\% of all the decorated sherds), as well as sherds with cane, fingernail, and tool punctated elements (24\%) (see Table 5). One rim sherd has diagonal incised lines and incised triangles filled with small circular punctations. 
Table 5. Decorated sherds from the Road Islands or Titus Islands site.

\begin{tabular}{|c|c|c|c|}
\hline Decorative element & Rim & Body & $\mathrm{N}$ \\
\hline \multicolumn{4}{|l|}{ Utility Ware } \\
\hline parallel appliqued ridge & - & 1 & 1 \\
\hline parallel brushed & - & 6 & 6 \\
\hline horizontal incised lines & 1 & & 1 \\
\hline parallel incised lines & - & 8 & 8 \\
\hline straight incised line & - & 3 & 3 \\
\hline $\begin{array}{l}\text { diagonal incised-circular punctated- } \\
\text { filled triangular zone }\end{array}$ & 1 & - & 1 \\
\hline cane punctated zone & - & 1 & 1 \\
\hline fingernail punctated rows & - & 3 & 3 \\
\hline tool punctated rows & - & 2 & 2 \\
\hline tool punctated, free & - & 2 & 2 \\
\hline Subtotal, utility wares & 2 & 26 & 28 \\
\hline \multicolumn{4}{|l|}{ Fine Ware } \\
\hline exterior red-slipped* & - & 1 & 1 \\
\hline diagonal opposed engraved lines & - & 1 & 1 \\
\hline $\begin{array}{l}\text { diagonal opposed engraved lines and } \\
\text { excised triangle area }\end{array}$ & 1 & - & 1 \\
\hline horizontal engraved lines & 1 & - & 1 \\
\hline straight engraved line & - & 1 & 1 \\
\hline Subtotal, fine wares & 2 & 3 & 5 \\
\hline Totals & 4 & 29 & 33 \\
\hline
\end{tabular}

In addition to one red-slipped bottle body sherd, the engraved fine wares include a Hickory Engraved rim and two Holly Fine Engraved rim and body sherds. The body sherd has fine diagonal and opposed engraved lines, while the rim sherd (likely from a carinated bowl, see Suhm and Jelks 1962:Plate 39a, e, g) has vertical and diagonal opposed sets of fine engraved lines that are separated by narrow vertical and triangular-shaped excised areas.

The lithic artifacts in the Roads Islands or Titus Islands site include four dart points, six bifaces. two ground stone tools, four cores, 101 pieces of lithic debris, and three quartzite fire-cracked rocks; most of these artifacts apparently relate to prehistoric occupations earlier than the Caddo occupation. The dart points are from both Woodland and Middle Archaic occupations. The Woodland period dart points consist of a Gary point (made from a local brownish-red chert), a Kent point made from a local red chert, and a Godley point of non-local gray novaculite. The possible Middle Archaic point in the collection, nade from a local quartzite, has shallow side notching and a resharpened blade. 
There are biface fragments and early stage bifaces in the documented collection, made from quartzite $(n=3)$, gray novaculite $(n=1)$, light gray chert $(n=1)$, and gray chert $(n=1)$. Both of the ground stone tools are grinding slab fragments of local ferruginous sandstone.

The cores are on heat-treated quartzite $(n=4)$ pebbles with multiple flake removals. The lithic debris is from several different raw materials: quartzite $(n=73)$, petrified wood $(n=7)$, hematite $(n=1)$, light gray chert $(n=1)$, gray chert $(n=18)$, and volcanic tuff $(n=1)$, possibly related to Manning Fuscd Glass, a raw material available primarily in the Neches, Sabine, and Trinity river basins in East Texas. More than $80 \%$ of the debris are from local raw materials (quartzite, petrified wood, and hematite), while the remainder (cherts and volcanic tuff) are from non-local raw material sources in East Texas and along the Red River to the north.

There is also a small $(n=12)$ assortment of historic artifacts from the previously noted historic occupation in the collections recently documented from the Roads Islands or Titus islands site. This includes cut nails (1820-1891, $n=1$ ), wire nails (post-1891, $n=2)$, stoneware sherds $(n=3)$, plain whiteware body sherds $(n=4)$, amber bottle glass $(n=1)$, and clear tableware glass $(n=1)$. This historic occupation probably dates from the late $19^{\text {th }}$ to the early $20^{\text {th }}$ century, based on the presence of both cut and wire nails, post-1870s salt glaze stoneware with an interior lead glaze, and early $20^{\text {th }}$ century Bristol glaze stoneware sherds, onc with a blue cobalt exterior.

\section{SUMMARY AND CONCLUSIONS}

A lengthy drought in East Texas in 2010 and 2011 has significantly lowered water levels at all artificial reservoirs in the region, Lake Bob Sandlin being no exception. The lower water levels have exposed landforms with previously recorded sites on them, among thein sites that had not been accessible since the late 1970s. Archaeological materials occur on them and are being collected by avocational archaeologists, as attested to by our recent documentation of prehistoric lithic and ceramic artifacts in avocational archaeological collections from five different sites at the lake: Dead Oak (41CP288), West Island (41TT208), East Island (41TT209), TXU Park and Boat Ramp (41TT758), and Road Islands or Titus Islands (41TT804).

These sites have evidence of prehistoric occupations in the now-inundated Big Cypress Creek valley that date as early as the Middle Archaic (ca. 8000-5000 cal years B.P.) to as late as the Late Caddo period (A.D. 1430-1680). Three of the five sites (Dead Oak, TXU Parks and Boat Ramp, and Road Islands or Titus Islands) were occupied during multiple periods, including Middle Archaic, Late Archaic, Woodland, Formative-Early Caddo, and Middle Caddo periods. The most intensive occupations at these three sites occurred betwcen ca. A.D. 850-1400, primarily after ca. A.D. 1200. In the case of the other two sites, they were apparently occupied only by Caddo pcoples in pre-A.D. 1200 (East Island), Middle Caddo (West Island), and Late Caddo limes (East Island). These Caddo occupations likcly represent domestic habitation sites that were occupied year-round by a small group of horticultural to agricultural peoples that lived in farmsteads and hamlets dispersed across the Big Cypress Creek valley. The Archaic and Woodland period components represent the encampments of relativcly mobile hunter-gatherer foragers, although some late Woodland sites in this part of East Texas may be the product of more sedentary occupations by peoples culturally related to later Caddo peoples. 


\section{REFERENCES CITED}

Brown, J.A.

1996 The Spiro Ceremonial Center. The Archaeology of Arkansas Valley Caddoan Culture in Eastern Oklahoma. 2 Vols. Memoir No. 29. Museum of Anthropology, University of Michigan. Ann Arbor.

Leibowitz, J.

1985 Yellow Ware: The Transitional Ceramic. Schiffer Publishing, Ltd., West Chester, Pennsylvania.

Nelson, B. and T. K. Perttula

2003 Archeological Survey along the Lake Bob Sandlin Shoreline, Camp, Franklin, and Titus Counties, Texas. Report of Investigations No. 46. Archeological and Environmental Consultants, LLC, Austin.

Perttula, T. K. and B. Nelson

2003 Temporal and Spatial Patterns in the Prehistoric Settlement of the Lake Bob Sandlin Area, Big Cypress Creek Basin, Northeastern Texas. Caddoan Archeology Journal 13(2):28-35.

Pertlula, T. K., M. Walters, and B. Nelson

2010 Documenting Caddo Ceramic Sherd and Lithic Collections from Prehistoric Sites at Lake Boh Sandlin. Journal of Northeast Texas Archaeology 33:31-39.

Story, D. A.

2000 Introduction. In The George C. Davis Site, Cherokee County, Texas, by H. P. Newell and A. D. Krieger, pp. 1-31. 2nd Edition. Society for American Archaeology, Washington, D.C.

Suhm, D. A. and E. B. Jelks (editors)

1962 Handbook of Texas Archeology: Type Descriptions. Special Publication No. 1, Texas Archeological Society, and Bulletin No. 4, Texas Memorial Muscum, Austin. Reprinted in 2009, Gustav's Library, Davenport, Iowa.

Turner, E. S., T. R. Hester, and R. L. McReynolds

2011 Stone Artifacts of Texas Indians: Completely Revised Third Edition. Taylor Trade Publishing, Lanham, Maryland. 